\title{
Optimism and Burnout in Competitive Sport
}

\author{
Rosendo Berengüí ${ }^{1}$, Enrique J. Garcés de los Fayos Ruiz ${ }^{2}$, \\ Francisco J. Ortín Montero ${ }^{2 *}$, Ricardo de la Vega Marcos ${ }^{3}$, José María López Gullón ${ }^{2}$ \\ ${ }^{1}$ Catholic University San Antonio of Murcia, Murcia, Spain \\ ${ }^{2}$ University of Murcia, Murcia, Spain \\ ${ }^{3}$ Autonomus University of Madrid, Madrid, Spain \\ Email: "ortin@um.es
}

Received July 23 ${ }^{\text {rd }}, 2013$; revised August 21 $1^{\text {st }}, 2013$; accepted September $16^{\text {th }}, 2013$

\begin{abstract}
Copyright @ $\odot 2013$ Rosendo Berengüí et al. This is an open access article distributed under the Creative Commons Attribution License, which permits unrestricted use, distribution, and reproduction in any medium, provided the original work is properly cited.
\end{abstract}

\begin{abstract}
The aim of this study was to analyze the relationship between optimism and burnout in the context of athletic competition. The sample was composed of 227 athletes that competed in wrestling at Spain's national level. For the assessment of constructs, the Spanish version by Otero et al. (1998) of the Life Orientation Test (LOT-R) was utilized, as well as the Inventario de Burnout para Deportistas (IBD), which was an adaptation for athletic populations by Garcés de Los Fayos (1999) of the Maslach Burnout Inventory (MBI) (Maslach \& Jackson, 1981). The results demonstrate a relationship between optimism and the three dimensions of burnout, in which the athletes who are more optimistic demonstrate less emotional exhaustion, less depersonalization, and a greater perception of personal accomplishment in their athletic performance.
\end{abstract}

Keywords: Optimism; Burnout; Athletic Competition

\section{Introduction}

Sport psychology studies, apart from other things; interpret the relationship between psychological variables, performance and health (Cote, Baker, \& Abernethy, 2003; Durand-Bush \& Salmela, 2002; López-López, Jaenes-Sánchez, \& CárdenasVélez, 2013). The study of personality in sport involves an extensive line of research (Cox, 2009; Vealey, 2002; Weinberg \& Gould, 2010). According to Valdés, (1998), studies are mainly oriented in two directions: 1) first analyzing how participation in sport influences on personality and 2) secondly analyzing the possibility of predicting individual differences and explain them in terms of personality or personality traits. Studies of personality and sport also seek age differences or even the influence of a profile on athletic performance (Ruiz \& García, 2013).

These two lines of consolidated research in sport psychology are related to some aspects of the personality such us the importance of optimism and the appearance of burnout syndrome. These two aspects have been recurrent observed in both, from athletes and in different professionals working in the sport environment (De la Vega, Ruiz, Rivera, \& Ortín, 2012, García \& Díaz, 2010; Garcés de los Fayos, Ortín, \& Carlin, 2010). The relationship between burnout and optimism has been studied in contexts such as education (Rothmann \& Essenko, 2007), work (Happell \& Koehn, 2011) or health (Sánchez \& Méndez, 2007). However, research studies focused on the context of physical activity and sport are much more scarce and the available references indicate a clear relationship between burnout and optimism, as we show later in this paper.

\footnotetext{
"Corresponding author
}

\section{Optimism and Sport}

Positive psychology has become a sound paradigm in the field of applied psychology and psychological research in recent years. The starting point was the address given by Martin Seligman to initiate his presidency of the American Psychological Association (Seligman, 1998). This discipline, supported by scientific research, studies the processes that underlie the positive emotions and attitudes of human beings as psychological processes and resources that prevent the manifestation of mental illness (De la Vega, Ruiz, Bastista, Ortín, \& Giesenow, 2012).

Among the most researched constructs within positive psychology is optimism, which has been studied in different contexts related to health and performance (Hefferon, 2012; Maruta, Colligan, Malinchoc, \& Oxford, 2000; Rees, Ingledew, \& Hardy, 2005; Remor, Amorós, \& Carrobles, 2006).

Optimism has mainly been analyzed from two theoretical perspectives. Firstly, there is the dispositional theory proposed by Scheier and Carver (1985), which is focused on the expectations that subjects have for the events that can happen to them. In this sense, a person with favorable expectations will increase his or her effort to achieve a goal (García \& Díaz, 2010). For this model, optimism and pessimism are generalized expectations, considered to be stable dispositions, or in other words, traits (Ferrando, Chico, \& Tous, 2002).

On the other hand, optimism has been studied from the theory of explanatory style, which was initiated by Abramson, Seligman and Teasdale in 1978 and has its origins in the most classic attribution theory (Weiner et al., 1971). The explanatory styles refer to the way people explain what happens to them (Isaacowitz, 2005; Shapcott, Bloom, Johnston, Loughead, \& 
Delaney, 2007). Thus, one's customary way of explaining their own experiences demonstrates an explanatory style that, from a theoretical point of view, has three fundamental dimensions: permanence, pervasiveness, and personalization (Abramson et al., 1978; Seligman, 2004).

The study of optimism as a psychological construct comes as a response to the reformulation of the Theory of Learned Helplessness by Abramson et al. (1978). In the athletic context, optimism is a construct of personality that acts as a decisive factor when the athlete finds himself in situations of pressure (Seligman, 2004), often making a difference between how the athletes manage adverse situations and face difficulties in similar situations (Martin-Krumm, Sarrazin, Peterson, \& Famose, 2003; Seligman, Nolen-Hoeksema, Thornton, \& Thornton, 1990).

Seligman et al. (1990) carried out a study with swimmers that became a reference for numerous subsequent studies (De la Vega et al., 2012; Ortín, Garcés de los Fayos, Gosálvez, Ortega, \& Olmedilla, 2011). In that study, the athletes were presented with a situation of defeat under controlled conditions, and the execution of each athlete in the same situation a few minutes later was observed. It is noteworthy that the pessimistic swimmers had worse results in the second situation. On the other hand, the optimistic subjects equaled or even improved on the times from the first situation.

Further, optimism in sport has been studied in relation to performance (García \& Díaz, 2010), the coaches' assessment of competition (Ortín, Ortega, López, \& Olmedilla, 2012), anxiety (Martin-Krumm et al., 2003), and confrontation (Holt \& Hogg, 2002; Nicholls, Polman, Levy, \& Backhouse, 2007).

\section{Burnout and Sport}

Burnout, is a tridimensional syndrome characterized by Emotional Exhaustion, Depersonalization (Cynicism), and Reduced Efficacy, continues to be a construct built around the contributions that various researchers have made. Following the work of Garcés de Los Fayos et al. (2010), we can affirm the following as aspects of burnout.

Predictor variables. Many researchers have described these variables both from a purely investigative perspective as well as a more applied perspective. At the end, all have been grouped into three large groups: social-familial, athletic, and personal (internal).

Consequences. There are many, from the most worrisome (dropout; Garcés de Los Fayos, \& Cantón, 2007) to others such as physical problems (illnesses and injuries), dissatisfaction with the lifestyle that one has, dissatisfaction with one's role in relation to sport, unfulfilled expectations, and feelings of isolation.

Theoretical models. On the other hand, various theoretical models have been offered which help us more clearly understand the development of the syndrome. Thus, models such as that by Smith (1986), based on the one which is utilized to explain the development of athletic stress; that by Schmidt and Stein (1991), supported by athletic commitment; that by Coakley (1992), which explains the syndrome through maladaptive social processes, and that by Garcés de Los Fayos and Cantón (2007), which is supported in large part by the unification of the three previous ones and currently allows us to frame this development rather precisely.

Epidemiological data. The epidemiological data are very relevant in the athletic context as they allow us to adequately contextualize the importance of the syndrome in the athletic population. Jiménez, Jara and García (1995) found that about $10 \%$ of athletes could be affected by burnout, and Tutte (2009) encountered similar results.

Measurement Instruments. Finally, it is also important to offer a reference about the strategies of evaluation that sport psychologists utilize to assess the presence of burnout in athletes. From this perspective, in our immediate context, there are two that are highly utilized: the MBI by Maslach and Jackson (1981), adapted by Garcés de Los Fayos (1999) and with some substantial modifications from the items in the original instrument, and the Athlete Burnout Questionnaire (ABQ) by Raedeke and Smith (2001), adapted by De Francisco, Arce, Andrade, Arce and Raedeke (2009).

\section{Optimism and Burnout in Sport}

Both burnout and optimism are related to the subject's personality. The studies of personality in the athletic context are numerous (Ruiz \& García, 2013). In this sense, there are studies that try to describe a specific personality profile in athletes of one sport or another (Bakker, Whiting, \& Van Der Drug, 1993; Cunha et al., 2010), and there are other studies that indicate individual differences in athletic performance in terms of personality (Ezquerro, 1997; Reche, Cepero, \& Rojas, 2010; Vives \& Garcés de los Fayos, 2002).

There are a limited number of studies that have assessed the relationship between optimism and burnout in any context. However, the data from these studies indicate a relationship been the two concepts, occasionally pointing to optimism as a protector variable when faced with burnout or some of its associated symptoms. Specifically, an inverse relationship between optimism and emotional exhaustion for workers of various professions has been found (Happell \& Koehn, 2011; Rothmann \& Essenko, 2007). This same relationship has been found in the athletic context, such that the athletes with an optimistic profile are more resistant to both physical and mental exhaustion, which could be explained by lower levels of tension (Gustafsson \& Skoog, 2012). Tsai, Chen, and Kee (2007) indicate that the different strategies of confrontation between optimistic and pessimistic athletes could be a possible mediator between optimism and emotional exhaustion. These authors also found a relationship between optimism and reduced efficacy.

Regarding the relationship between optimism and overall burnout, Chen, Kee, and Tsai (2008) studied 139 volleyball players and found that the athletes' optimism scores were negatively related to the burnout scores. Later, Gustafsson and Skoog (2012) corroborated these findings in a sample of 217 athletes, when they found an inverse relationship between perceived stress, burnout, and optimism.

The aim of this study was to analyze the relationship between optimism and pessimism and burnout in competitive wrestlers.

\section{Method}

\section{Participants}

The sample was composed of 227 wrestlers that participated in the Spanish wrestling championship, 165 males (72.69\%) and 62 females $(27.31 \%)$. The mean age was 20.16 years, with a range from 15 to 31 years. A simple sampling was carried out. It was a wide size population, because the sample included the 
$87 \%$ of participants in the competition.

\section{Instruments}

Inventario de Burnout para Deportistas (IBD). This instrument is the adaptation of the Maslach Burnout Inventory (Maslach \& Jackson, 1981) by Garcés de Los Fayos (1999) for athletic populations. It is composed of 26 items, grouped into three dimensions: Emotional Exhaustion, Depersonalization (Cynicism), and Reduced Efficacy. A five-point Likert scale was utilized for responses, from 1 ("I have never felt or thought this") to 5 ("I think or feel this daily"). Percentiles greater than 66 in Emotional Exhaustion and Cynicism and below 33 in Reduced Efficacy would indicate burnout (Garcés de Los Fayos, 2004). The reliability coefficient (Cronbach's alpha) for each of the scales was $\alpha=.746$ for Emotional Exhaustion, $\alpha=.757$ for Reduced Efficacy, and $\alpha=.757$ for Cynicism. As far as validity is concerned, Garcés de Los Fayos (1999) notes that the MBI is the most appropriate instrument for burnout measurement, and after the realized adaptation it shows rates making it a perfectly applicable inventory to the athletes population.

Life Orientation Test (LOT-R). The Spanish adaptation (Otero et al., 1998) of the test by Scheier and Carver (1985) in the review by Scheier, Carver, and Bridges (1994) was utilized. This is composed of 10 items and utilizes a 5-point Likert scale from 0 (strongly disagree) to 4 (strongly agree). Among the 10 items, three are written in a positive sense (optimism measure) and three are written in a negative sense (pessimism measure), while the final four are fillers. For the interpretation of the test, the researchers followed different criteria. Some studies contemplate each factor, optimism and pessimism, separately (Mroczek, Spiro, Aldwin, Ozer, \& Bosse, 1993; Myers \& Steed, 1999). Other authors (De la Vega et al., 2012; Ortín et al., 2011) subtract the values obtained for pessimism from the values obtained for optimism, thereby assuming that the athlete's tendency is optimism if he or she obtains positive values and pessimism is the values are negative. In the present study, the second option was utilized. The reliability coefficient (Cronbach's alpha) that was obtained in the optimism scale was $\alpha$ $=.744$ and it was $\alpha=.718$ in the pessimism scale. Respected to the validity, Ferrando et al. (2002) carry out a psychometric analysis of this test and obtain relatively high validity coefficients, marking that the actual version of the questionnaire shows a performance at least equally acceptable as the original scale.

\section{Procedure}

Permission was granted from the Spanish Federation of Associated Wrestling Styles as well as all of their individual state member federations before the study took place. The questionnaires were administered during the Spanish Wrestling Championship for the categories of Cadet and Senior after the objectives were explained to them. Data collection was carried out before the athletes' medical exams and weigh-in. Information about the study was provided to the athletes and any questions were answered.

\section{Statistical Analysis}

Various statistical analyses were utilized: specifically, standard statistical methods to calculate means and standard deviation (SD), analysis of correlation (Pearson's coefficient) to observe the average variation between the scores of the scales from the IBD and LOT-R, and Student t-test for independent samples for assessing the differences between the various groups. Grouping was done to analyze the differences in average optimism and pessimism for subjects with low and high scores in the scales of the IBD. For that, a standard deviation was either subtracted (for the low group) or added (for the high group) to the scale's mean. Therefore, to obtain the optimistic-pessimistic tendency of the athlete, the criteria of Ortín et al. (2011) were followed, in which the values obtained by the participant in pessimism were subtracted from the values obtained in optimism. Thus, when positive values were obtained, an optimistic tendency was assumed, and when negative values were obtained, a pessimistic tendency was assumed. For all cases, statistical significance was set at $5 \%(p \leq .05)$, and the analysis of the data was done with the SPSS program (version 15.0, SPSS Inc., Chicago, IL, USA).

\section{Results}

Table 1 demonstrates the descriptive data from each scale of the IBD and the LOT-R for the total samples. It should be pointed out that 84 athletes, $37 \%$ of the total, presented some of the characteristics of burnout proposed by Garcés de Los Fayos (1999); that is, higher than 66\% in Emotional Exhaustion and Depersonalization and below 33\% in Reduced Efficacy. Specifically, 13 subjects had values above $66 \%$ for Emotional Exhaustion, 15 subjects had values above $66 \%$ for Depersonalization, and 27 had values above $66 \%$ for Reduced Efficacy. Eleven percent ( 25 subjects) had high scores on two scales, and 18 of those subjects had their high scores in Emotional Exhaustion and Depersonalization. Four subjects $(1.76 \%$ of the sample) scored high on all three scales.

Regarding the distinction between optimistic and pessimistic athletes, the pessimistic athletes represented $19.82 \%$ of the sample (or 45 subjects), and they were characterized by scoring negatively when subtracting their Optimism score from their Pessimism score.

After grouping the subjects who scored low and high in the various scales of the Inventario de Burnout en Deportistas from the addition or subtraction of a standard deviation from the scale's mean, results that indicate various differences between these groups were obtained. Thus, the athletes with low scores in Emotional Exhaustion $(n=38)$ had significantly different scores from those athletes in the high-scoring group $(n=33)$ (Table 2); specifically, they have higher means in Optimism $\left(t_{69}=3.565 ; p=.001\right)$ and Tendency toward optimism $\left(t_{69}=\right.$ $3.732 ; p=.000)$. The differences are partially significant for

Table 1.

IBD and LOT-R results.

\begin{tabular}{ccccc}
\hline & Minimum & Maximum & Mean & SD \\
\hline Emotional Exhaustion & 7 & 30 & 17.09 & 4.917 \\
Depersonalization & 10 & 36 & 18.87 & 6.556 \\
Reduced Efficacy & 10 & 40 & 27.33 & 6.562 \\
Optimism & 0 & 12 & 8.00 & 2.652 \\
Pessimism & 0 & 11 & 4.97 & 2.636 \\
Tendency toward Optimism & -6 & 12 & 3.03 & 3.930 \\
\hline
\end{tabular}


Table 2.

Differences in groups scoring low and high for emotional exhaustion.

\begin{tabular}{cccccc}
\hline & \multicolumn{2}{c}{ Low $(\mathrm{n}=38)$} & \multicolumn{2}{c}{ High $(\mathrm{n}=33)$} & \multirow{2}{*}{$t(d f=69)$} \\
\cline { 2 - 5 } & Mean & SD & Mean & SD & \\
\hline Optimism & 9.29 & 3.013 & 6.94 & 2.461 & $3.565^{* *}$ \\
Pessimism & 4.39 & 2.595 & 5.48 & 2.360 & -1.841 \\
$\begin{array}{c}\text { Tendency } \\
\text { toward Optimism }\end{array}$ & 4.89 & 3.951 & 1.45 & 3.784 & $3.732^{* *}$ \\
\hline${ }^{* *} p<.01$. & & & & & \\
\end{tabular}

Pessimism $\left(t_{69}=-1.841 ; p=.070\right)$, where the high-scoring group's subjects obtained higher scores for Emotional Exhaustion.

After carrying out an identical analysis with the Depersonalization scale (Table 3), differences can be observed in the three elements from the LOT-R. This includes greater Optimism $\left(t_{80}\right.$ $=2.054 ; p=.044)$ and Tendency toward optimism $\left(t_{80}=3.708\right.$; $p=.000$ ) for athletes in the group of low Depersonalization (n $=42)$ while the subjects in the high-scoring group $(n=40)$ had a higher mean (6.05) in Pessimism $\left(t_{80}=3.708 ; p=.000\right)$.

For Reduced Efficacy, Table 4 presents the descriptive variables for the groups and the differences that were found. Contrary to the Emotional Exhaustion sub-scale, the athletes with low scores in Reduced Efficacy $(n=35)$ scored significantly differently from those with high scores $(n=39)$, and they recorded lower mean scores for Optimism $\left(t_{72}=-4.926 ; p=.000\right)$ and Tendency toward optimism $\left(t_{72}=-4.502 ; p=.000\right)$.

Finally, a comparison between athletes with an optimistic tendency (positive values; $\mathrm{n}=182$ ) and those with a pessimistic tendency (negative values; $\mathrm{n}=45$ ) is demonstrated in Table 5 . The wrestlers with a tendency toward optimism had lower mean scores for Emotional Exhaustion (16.70) and Depersonalization (18.47), and they had higher means for Reduced Efficacy (28.02). There are statistically significant differences between the two groups for Emotional Exhaustion $\left(t_{225}=2.424 ; p\right.$ $=.016)$ and Reduced Efficacy $\left(t_{225}=-3.233 ; p=.001\right)$, and the differences in Depersonalization $\left(t_{225}=1.883 ; p=.061\right)$ were partially significant.

\section{Conclusion}

Competitive sport occasionally involves stressful situations for the athletes (Ortín et al., 2011). Monitoring these situations and some strategies for suitable confrontation are two of the most important aspects for performance (García \& Díaz, 2010).

The aim of this study is to analyze the relationship between optimistic and pessimistic profiles and the various dimensions that compose the syndrome of burnout: emotional exhaustion, depersonalization (or cynicism), and reduced efficacy.

The results indicate that $37 \%$ of the athletes have an unhealthy level of some of the three dimensions of burnout. Regarding optimism and pessimism, $80.18 \%$ have at least a tendency toward optimism, which has been found in other studies when this construct has been studied in performance sport (Gordon, 2008; Norlander \& Archer, 2002; Wilson, Raglin, \& Pritchard, 2002).

Regarding the relationship between optimism and burnout, the results to be highlighted are the following. On one hand, the optimistic athletes demonstrate less emotional exhaustion. This
Table 3.

Differences in groups scoring low and high for Depersonalization.

\begin{tabular}{cccccc}
\hline & \multicolumn{2}{c}{ Low $(\mathrm{n}=42)$} & \multicolumn{2}{c}{ High $(\mathrm{n}=40)$} & \multirow{2}{*}{$t(d f=80)$} \\
\cline { 2 - 5 } & Mean & $\mathrm{SD}$ & Mean & $\mathrm{SD}$ & \\
\hline Optimism & 8.67 & 3.175 & 7.43 & 2.241 & $2.054^{*}$ \\
Pessimism & 4.02 & 2.571 & 6.05 & 2.438 & $-3.658^{* *}$ \\
$\begin{array}{c}\text { Tendency } \\
\text { toward Optimism }\end{array}$ & 4.64 & 4.077 & 1.38 & 3.894 & $3.708^{* *}$ \\
${ }^{*} p<.05 ;{ }^{* *} p<.01$. & & & & & \\
\end{tabular}

Table 4.

Differences in groups scoring low and high for Reduced Efficacy.

\begin{tabular}{cccccc}
\hline & \multicolumn{2}{c}{$\operatorname{Low}(\mathrm{n}=35)$} & \multicolumn{2}{c}{$\operatorname{High}(\mathrm{n}=39)$} & \multirow{2}{*}{$t(d f=72)$} \\
\cline { 2 - 5 } & Mean & SD & Mean & SD & \\
\hline Optimism & 6.91 & 3.033 & 9.74 & 1.817 & $-4.926^{* *}$ \\
$\begin{array}{c}\text { Pessimism } \\
\text { Tendency }\end{array}$ & 5.49 & 2.582 & 4.51 & 2.771 & 1.557 \\
toward Optimism & 1.43 & 3.509 & 5.23 & 3.731 & $-4.502^{* *}$ \\
\hline
\end{tabular}

${ }^{* *} p<.01$.

Table 5.

Differences between pessimists and optimists in IBD.

\begin{tabular}{|c|c|c|c|c|c|}
\hline & \multicolumn{4}{|c|}{ Pessimist $(n=45)$ Optimist $(n=182)$} & \multirow{2}{*}{$t(d f=225$} \\
\hline & Mean & SD & Mean & SD & \\
\hline Emotional Exhaustion & 18.67 & 5.018 & 16.70 & 4.827 & $2.424^{*}$ \\
\hline Depersonalization & 20.51 & 6.717 & 18.47 & 6.470 & 1.883 \\
\hline Reduced Efficacy & 24.56 & 5.941 & 28.02 & 6.542 & $-3.233^{* *}$ \\
\hline
\end{tabular}

aspect is the one that has been most reflected in the scientific literature in various contexts (Gustafsson \& Skoog, 2012; Happell \& Koehn 2011; Rothmann \& Essenko, 2007). In relation to depersonalization, the data are similar, such that the most optimistic athletes demonstrate lower scores for this dimension. Finally, for reduced efficacy, the data again demonstrate a possible healthy effect of optimism, like the optimistic subjects have a higher score in this dimension. The results are similar if the results are analyzed by utilizing the dimensions of burnout as a reference as well as when using the optimist-pessimist profile as a reference.

\section{Discussion}

The scientific literature indicates that optimism favors health. Studies indicate that, among other aspects, optimism can reduce the physical symptoms of illnesses and improves strategies of confrontation (Scheier \& Carver, 1985), it favors a more complete and flexible cognitive process (Aspinwall, Richter, \& Hoffman, 2001), and it helps the person to evaluate the present and look for better opportunities in the future (Schneider, 2001). Along these lines, if burnout is considered a clinical syndrome that affects the subject's health, the analysis of the relationship between the two constructs may be relevant in any context. 
Thus, psychological interventions may be beneficial in helping athletes learn strategies to gain optimism. Some intervention programs have found positive results along these lines (Sánchez \& Méndez, 2007). Among the aspects that should be highlighted from the interventions is the work done on explanatory style and attributes in Seligman's theoretical line (Sanjuán et al., 2008). The work on optimism may act as a protector when presented with psychological problems such as the appearance of burnout.

Working on these psychological variables can be done by several professionals working with the athlete. Keeping in mind the importance of the coach, the education of the coach regarding the handling of optimistic messages, a suitable reinforcement, and correct attributions may positively affect the athletes. Seligman (2004) upholds the existence of optimistic and pessimistic teams strongly affected by the leadership style of the coaches. The explanatory style of a coach may affect the analysis of the results, and in this way influence the feedback that is given to the athletes (Ortín et al., 2012).

Optimism and the prevention of burnout are two aspects that can be learned. In the area of research, there are also validated tests that are specific for each construct. In the present study, the two that are most utilized in the athletic context according to the bibliometric study by Ortín, Marín and Garcés de los Fayos (2012) were used.

Is important to note some limitations of our study, in order to guide future research on optimism and burnout. First at all, it should be marked that this study has been done with a sample in a particular sport. In this sense, it may be interesting to carry out a similar analysis in other sports, including both individual and team sports. On the other hand, although we can observe some statistically significant data in certain burnout scales, it could be relevant to investigate what has produced these results, analyzing the influence of people surrounding the athlete like the coach and the family. Analyzing these causes will favor the possibility to create prevention and intervention programs on burnout and promoting optimism in the context of physical activity and sport.

\section{REFERENCES}

Abramson, L. Y., Seligman, M. E. P., \& Teasdale, J. D. (1978). Learned helplessness in humans: Critique and reformulation. Journal of Abnormal Psychology, 87, 49-74. doi:10.1037/0021-843X.87.1.49

Aspinwall, L. G., Richter, L., \& Hoffman, R. R. (2001). Understanding how optimism works: An examination of optimists' adaptive moderation of belief and behavior. In E. D. Chand (Ed.), Optimism and pessimism. Implications for theory research and practice (pp. 217238). Washington DC: American Psychological Association.

Bakker, F., Whiting, H. T., \& Van Der Brug, H. (1993). Psicología del deporte. Conceptos y aplicaciones. Madrid: Morata.

Chen, L. H., Kee, Y. H., \& Tsai, Y. M. (2008). Relation of dispostitional optimism with burnout among athletes. Perceptual \& Motor Skills, 106, 693-698. doi:10.2466/pms.106.3.693-698

Coakley, J. (1992). Burnout among adolescente athletes: A personal failure or social problem. Sociology of Sport Journal, 9, 271-285.

Cote, J., Baker, J., \& Abernethy, B. (2003). From play to practice: A developmental framework for the acquisition of expertise in team sport. In J. Starkes, \& K. A. Ericsson (Eds.), Recent advances in research on sport expertise (pp. 89-114). Champaign, IL: Human Kinetics.

Cox, R. H. (2009). Psicología del deporte: Conceptos y sus aplicaciones (6th ed.). Madrid: Editorial Médica Panamericana.

Cunha, G., Mesquita, I., Moreno, P., Boleto, A., Tavares, T., \& Silva, P. (2010). Autopercepción de las competencias profesionales de fútbol en función de la experiencia y de la formación académica. Cuadernos de Psicología del Deporte, 10, 23-36.

De Francisco, C., Arce, C., Andrade, E., Arce, I., \& Raedeke, T. (2009). Propiedades preliminares de la versión española del athelete burnout questionnaire en una muestra de jóvenes futbolistas. Cuadernos de Psicología del Deporte, 9, 45-56.

De la Vega, R., Ruiz, R., Batista, F., Ortín, F. J., \& Giesenow, C. (2012). Effects of feedback on self-efficacy expectations based on the athlete's optimistic profile. Psychology, 3, 1208-1214.

doi:10.4236/psych.2012.312A179

De la Vega, R., Ruiz, R., Rivera, O., \& Ortín, F. J. (2012). Aplicación de una prueba objetiva conductual de evaluación de la influencia de los otros en el rendimiento en fútbol. Cuadernos de Psicología del Deporte, 12, 83-90. doi:10.4321/S1578-84232012000200009

Durand-Bush, N., \& Salmela, J. H. (2002). The development and maintenance of expert athletic performance: Perceptions of world and Olympic champions. Journal of Applied Sport Psychology, 14, 154171. doi:10.1080/10413200290103473

Ferrando, P. J., Chico, E., \& Tous, J. M. (2002). Propiedades psicométricas del test de optimismo life orientation test. Psicothema, 14, 673-680.

Garcés de Los Fayos, E. J. (1999). Burnout en deportistas: un estudio de la influencia de variables de personalidad, sociodemográficas y deportivas en el síndrome. Unpublished Dissertation, Murcia: Universidad de Murcia.

Garcés de los Fayos, E. J. (2004). Burnout en deportistas: Propuesta de un sistema de evaluación e intervención integral. Madrid: EOS.

Garcés de Los Fayos, E. J., \& Cantón, E. (2007). Un modelo teórico descriptivo del burnout en deportistas: Una propuesta tentativa. Informació Psicológica, 91-92, 12-22.

Garcés de Los Fayos, E. J., Ortín, F., \& Carlin, M. (2010). Burnout en el contexto deportivo: Análisis teórico práctico del estado de la cuestión. Apuntes de Psicología, 28, 213-224.

García, A., \& Díaz, F. (2010). Relación entre optimismo/pesimismo disposicional, rendimiento y edad en jugadores de fútbol de competición. Revista Iberoamericana de psicología del ejercicio y el deporte, 5, 45-60.

Gordon, R. A. (2008). Attributional style and athletic performance: Strategic optimism and defensive pessimism. Psychology of Sport and Exercise, 9, 336-350. doi:10.1016/j.psychsport.2007.04.007

Gustafsson, H., \& Skoog, T. (2012). The mediational role of perceived stress in the relation between optimism and burnout in competitive athletes. Anxiety, Stress and Coping, 25, 183-199. doi:10.1080/10615806.2011.594045

Happell, B., \& Koehn, S. (2011). Seclusion as a necessary intervention: The relationship between burnout, job satisfaction and therapeutic optimism and justification for the use of seclusion. Journal of Advanced Nursing, 67, 1222-1231. doi:10.1111/j.1365-2648.2010.05570.x

Hefferon, K. (2012). Bringing back the body into positive psychology: The theory of corporeal posttraumatic growth in breast cancer survivorship. Psychology, 3, 1238-1242. doi: 10.4236/psych.2012.312A 183

Holt, N. L., \& Hogg, J. M. (2002). Perceptions of stress and coping during preparations for the 1999 women's soccer world cup finals. The Sport Psychologist, 16, 251-271.

Isaacowitz, D. M. (2005). Correlates of well-being in adulthood and old age: A tale of two optimisms. Journal of Research in Personality, 39, 224-244. doi:10.1016/j.jrp.2004.02.003

Jiménez, G., Jara, P., \& García, C. (1995). Variables relevantes en el contexto deportivo y síndrome de burnout. Estudio presentado en el $V$ Congreso Nacional de Psicología de la Actividad Física y el Deporte. Valencia.

López-López, I., Jaenes-Sánchez, J. C., \& Cárdenas-Vélez, D. (2013). Adaptación para futbolistas del (CPRD-F) cuestionario de características psicológicas relacionadas con el rendimiento deportivo (CPRD). Cuadernos de Psicología del Deporte, 13, 21-30.

Martin-Krumm, C. P., Sarrazin, P. G., Peterson, C., \& Famose, J. P. (2003). Explanatory style and resilience after sport failure. Personality and Individual Differences, 35, 1685-1695. 
doi:10.1016/S0191-8869(02)00390-2

Maruta, T., Colligan, R. C., Malinchoc, M., \& Offord, K. P. (2000). Optimists vs. pessimists: Survival rate among medical patients over a 30-year period. Clinic Proceedings, 75, 140-143.

Maslach, C., \& Jackson, S. E. (1981). MBI: Maslach burnout inventory. manual. Palo Alto, CA: University of California, Consulting Psychologists Press.

Mroczek, D. K., Spiro III, A., Aldwin, C. M., Ozer, D. J., \& Bosse, R. (1993). Construct validation of optimism and pessimism in older men: Findings from the normative aging study. Health Psychology, 12, 406-409. doi:10.1037/0278-6133.12.5.406

Myers, L. B., \& Steed, L. (1999). The relationship between dispositional optimism, dispositional pessimism, repressive coping and trait anxiety. Personality and Individual Differences, 27, 1.261-1.272. doi:10.1016/S0191-8869(99)00071-9

Nicholls, R. A., Polman, C. J. R., Levy, A. R., \& Backhouse, S. H. (2007). Mental toughness, optimism, pessimism, and coping among athletes. Personality and Individual Differences, 44, 1182-1192. doi:10.1016/j.paid.2007.11.011

Norlander, T., \& Archer, T. (2002). Predicting performance in ski and swim championships: Effectiveness of mood, perceived exertion, and dispositional optimism. Perceptual and Motor Skills, 94, 153-164. doi:10.2466/pms.2002.94.1.153

Ortín, F. J., Ortega, E., López, E., \& Olmedilla, A. (2012). Estilos explicativos de los entrenadores de fútbol profesional en el análisis de la competición deportiva. Anales de Psicología, 28, 233-239.

Otero, J. M., Luengo, A., Romero, F., Gómez, J. A., \& Catro, C. (1998). Psicología de la personalidad. Manual de prácticas. Barcelona: Ariel Practicum.

Raedeke, T. D., \& Smith, A. (2001). Development and preliminary validation of an athlete burnout measure. Journal of Sport \& Exercise Psychology, 23, 281-306.

Reche, C., Cepero, M., \& Rojas, F. J. (2010). Efecto de la experiencia deportiva en las habilidades psicológicas de esgrimistas de ranking nacional español. Cuadernos de Psicologia del Deporte, 10, 33-42.

Rees, T., Ingledew, D. K., \& Hardy, L. (2005). Attribution in sport psychology: Seeking congruence between theory, research, and practice. Psychology of Sport and Exercise, 6, 189-204.

Remor, E., Amorós, M., \& Carrobles, J. A. (2006). El optimismo y la experiencia de ira en relación con el malestar físico. Anales de Psicología, 22, 37-44.

Rothmann, S., \& Essenko, N. (2007). Job characteristics, optimism, burnout, and ill health of support staff in a higher education institution in South Africa. South African Journal of Psychology, 37, 135152. doi: $10.1177 / 008124630703700110$

Ruiz, R., \& García, A. (2013). Personalidad, edad y rendimiento deportivo en jugadores de fútbol desde el modelo de Costa y McCrae. Anales de Psicología, 13. In press.

Sánchez, O., \& Méndez, F. X. (2007). Prevención de la depresión infantil mediante el fomento del optimismo. Revista de Psicoterapia, $18,77-89$.

Sanjuán, P., Pérez-García, A. M., Rueda, B., \& Ruiz, M. A. (2008). Estilos explicativos y afecto negativo. Revista de Psicopatología y Psicología Clínica, 13, 45-52.

Scheier, M. F., Carver, C. S., \& Bridges, M. W. (1994). Distinguishing optimism from neuroticism (and trait anxiety, self mastery and self esteem): A reevaluation of the life orientation test. Journal of Personality and Social Psychology, 67, 1063-1078. doi:10.1037/0022-3514.67.6.1063

Scheier, M., \& Carver, C. S. (1985). Optimism, coping, and health: Assessment and implication of generalized outcome expectancies. Health Psychology, 4, 219-247. doi:10.1037/0278-6133.4.3.219

Schmidt, G. W., \& Stein, G. L. (1991). Sport commitment: A model integrating enjoyment, dropout, and burnout. Journal of Sport and Exercise Psychology, 13, 254-265.

Schmidt, G. W., \& Stein, G. L. (1991). Sport commitment: A model integrating enjoyment, dropout, and burnout. Journal of Sport and Exercise Psychology, 13, 254-265.

Schneider, S. L. (2001). In search of realistic optimism. American Psychologist, 56, 250-263. doi:10.1037/0003-066X.56.3.250

Seligman, M. E. P. (1998). The president's address. American Psychologist, 54, 559-562.

Seligman, M. E. P. (2004). Aprenda optimismo. Madrid: Debolsillo.

Seligman, M. E. P., Nolen-Hoeksema, S., Thornton, N., \& Thornton, K. M. (1990). Explanatory style as a mechanism of disappointing athletic performance. Psychological Science, 1, 143-146. doi:10.1111/j.1467-9280.1990.tb00084.x

Shaffer, J. (2012). Neuroplasticity and positive psychology in clinical practice: A review for combined benefits. Psychology, 3, 1110-1115. doi:10.4236/psych.2012.312A164

Shapcott, J. B., Bloom, G. A., Johnston, K. M., Loughead, T. M., \& Delaney, J. S. (2007). The effects of explanatory style on concussion outcomes in sport. Neuro Rehabilitation, 22, 161-167.

Smith, R. E. (1986). Toward a cognitive-affective model of athletic burnout. Journal of Sport Psychology, 8, 36-50.

Tsai, Y. M., Chen, L. H., \& Kee, Y. H. (2007). The influence of optimism on athlete burnout. Journal of Sport and Exercise Psychology, 29, S208.

Tutte, V. (2009). Riesgo de abandono deportivo en jóvenes futbolistas. Unpublished dissertation. Barcelona: Universidad Autónoma de Barcelona.

Valdés, H. M. (1998). Personalidad y deporte. Barcelona: Editorial Inde.

Vealey, R. S. (2002). Personality and sport behavior. In T. S. Horn (Ed.), Advances in sport psychology (2nd ed., pp. 43-74). Champaign, IL: Human Kinetics.

Vives, L., \& Garcés de Los Fayos, E. J. (2002). Autoconfianza y deporte: Aportaciones de de la psicología del deporte para su optimización. In A. Olmedilla, E. J. Garcés de Los Fayos, \& G. Nieto (eds.), Manual de psicología del deporte (pp. 235-257). Murcia: Diego Marín.

Weinberg, R., \& Gould, D. (2010). Fundamentos de psicología del deporte y del ejercicio físico. Madrid: Editorial Médica Panamericana.

Weiner, B., Frieze, I. H., Kukla, A., Reed, L., Rest, S., \& Rosenbaum, R. M. (1971). Perceiving the causes of success and failure. Morristown, NJ: General Learning Press.

Wilson, G. S., Raglin, J. S., \& Pritchard, M. E. (2002). Optimism, pessimism, and precompetition anxiety in college athletes. Personality and Individual Differences, 32, 893-902. doi:10.1016/S0191-8869(01)00094-0 